\title{
浸透圧を利用した塩分濃度差発電の性能に及ぼす塩分濃度の影響*
}

\author{
荒井義 樹*1, 安ヶ平 和一*2, 庵 原 昭 夫*3
}

\section{Effect of Salt Concentration on Performance of Hydroelectic Power Station due to Osmotic Pressure}

\author{
Yoshinori ARAI, Waichi YASUGAHIRA*4 and Akio IHARA \\ ${ }^{* 4}$ Department of Mechanical Systems Engineering, Utsunomiya University, \\ 7-1-2 Youtou, Utsunomiya-shi, Tochigi, 321-8585 Japan
}

\begin{abstract}
This paper presents an experimental study about a possibility of a hydroelectric power station due to osmotic pressure generated between sea water and river water. The experiment is conducted by a newly constructed equipment using a spiral reverse osmotic module with membrane surface area $4.318 \mathrm{~m}^{2}$. The equipment can be pressured up to $0.5 \mathrm{MPa}$ to avoid a generation of bubble in pure and salt water channels. Tap water and salt water are used for experiment instead of river water and sea water. On the way of tap water passage, a valve is inserted to generate a loss corresponding to a hydraulic turbine load. Using a pump, salt water is forced to circulate and its flow rate is variable. The flow rate of tap water and the pressure difference between the valve inlet and outlet are measured with varying salt concentration from $0.1 \mathrm{wt} \%$ to $0.6 \mathrm{wt} \%$ and salt water flow rate from 3.5 $1 / \mathrm{min}$ to $5.0 \mathrm{l} / \mathrm{min}$. In these experiments we can obtain a maximum output about $0.86 \mathrm{~W}$ at salt concentration $0.6 \mathrm{wt} \%$. From these results, we had a confidence to construct the hydraulic power station utilizing osmotic pressure.
\end{abstract}

Key Words : Osmotic Pressure, Hydraulic Power Station, Sea Water, River Water

\section{1. 緒言}

ここで述べる塩分濃度差発電とは, 河川の真水を河 口の上流部において取水し，浸透膜を介して海水中へ と放出することで得られる浸透圧により, 水力発電に 必要とされる流量と落差を確保しようというものであ る.これまでの研究(1) (3)によると, 本方式の発電に よって, 日本の主要河川を利用するだけでも 1000 MW 級の原子力発電所数台分に相当する発電が見込 まれている。

本研究では, 実験に好適な浸透膜モジュールが市販 されていないことから, 市販の逆浸透膜モジュールを 用いて超小型の浸透圧塩分濃度差発電システムを構築 し, 加圧下でのシステムの発電性能を実験的に求めよ うとするものである. 加圧する理由は, 大気圧下でシ ステムを作動させると, 浸透圧により浸透膜モジュー ル内真水流路が負圧となり, 内部に気泡が発生して浸 透流量が著しく低下することが予想されることから，

* 原稿受付 2008 年 3 月 5 日.

*1 元: 宇都宮大学大学院工学研究科 [現: 三菱重工業(株) （丞108-8215 東京都港区港南 2-16-5) ].

*2 正員, 宇都宮大学工学部(亚321-8585 宇都宮市陽東 7-1-2).

*3 正員, フェロー, 元 : 宇都宮大学工学部.

E-mail : waichiy@cc.utsunomiya-u.ac.jp
それを防ぐためである，実験には河川水の代わりに水 道水を, 海水の代わりに塩水を使用した。 また，真水 の流入により塩水側膜表面の塩分濃度が低下するのを 低減させるために, 塩水をポンプにより強制的に流動 させた。

\section{2. 発 電 原 理}

水力発電における水車の出力 $W$ は次の式で表され る。

$$
W=\eta Q \Delta p=\eta \rho g H Q
$$

ここで $\eta$ は水車効率, $Q$ は流量, $\rho$ は水の密度, $g$ は 重力加速度, $H$ は落差である. 本発電方式においても 式（１）がそのまま適用できる. $\Delta p$ は水車負荷に相当 する. また, 浸透膜を透過する真水の流量 $Q$ は, 浸透 流速 $u_{W}$ と膜面積 $F$ の積によって求められる.ここ で浸透流速 $u_{W}$ は以下の式で求めることができる(4).

$$
\begin{aligned}
u_{W} & =A(\Delta \pi-\Delta p) \\
& =A\left[b\left(\rho_{S}-\rho_{W}\right)-\Delta p\right] .
\end{aligned}
$$

ここで, $A$ は真水の透過係数, $\Delta p$ は水車負荷および 管路損失の和, $\Delta \pi$ は浸透圧である。また, $b$ は浸透 圧を塩分濃度から簡易的に求めるための係数, $\rho_{S}$ は 塩水側膜近傍における塩分濃度, $\rho_{W}$ は真水側膜近傍 の塩分濃度である。本研究における実験では, $\Delta p$ は 
真水流路内に設けたバルブによって与えることとし, $Q$ は真水流路の流量によって与えるものとする.

\section{3. 実験装置および実験方法}

図 1 に本研究で製作, 使用した実験装置の概略を示 す.

装置は真水流路と塩水流路からなり, 真水流路と塩 水流路との接点に浸透膜が設置してある. 浸透膜には 海水から真水を逆浸透により抽出するために使用され ている膜面積 $4.318 \mathrm{~m}^{2}$, 耐圧 6.9 $\mathrm{MPa}$ のスパイラル 型逆浸透膜モジュール(日東電工製 NTR-70 SWC S 4) を使用した. 真水流路および塩水流路の両系は, 浸透によって真水流路が負圧となり気泡が発生するこ とを抑えるために, コンプレッサにより等しく加圧で きるようにした. 加圧可能な最大圧力はおよそ 0.7 $\mathrm{MPa}$ である。これは真水と海水(塩分濃度 $3.5 \mathrm{wt} \%$ ) との間に発生する浸透圧 $2.8 \mathrm{MPa}$ に対して低い值で あるが, 実験には塩分濃度 $0.6 \mathrm{wt} \%$ (浸透圧 0.48 $\mathrm{MPa})$ 以下の塩水を用いることにより, $0.5 \mathrm{MPa}$ の加 圧でも真水流路内が負圧になることを防ぎ, 気泡の発 生を抑えるのに十分な圧力となるようにした. 真水流 路には水車負荷に相当する損失を与えるためのバルブ を挿入し, その開度を調節することにより損失量を変 化させた. そのバルブ前後の圧力を圧力計により計測 し, バルブ前後差圧を算出した.さらに真水流路には 微少流量計を扦入し, 浸透流量を計測した.

また, 真水の浸透による塩水側膜面近傍の濃度低下 を防ぐために, 塩水はポンプにより強制的に循環させ, 循環させる塩水の流量および圧力を計測した. 製作し た装置では塩水と浸透した真水が混合して塩水タンク に戻り, それが再度塩水流路に流し込まれる仕組みと なっている.そのため長時間の運転では塩分濃度の低 下が心配されることから, 真水の浸透流量に比べて塩 水タンクの容積を十分に大きくした. 試作した装置の 30 分の作動時間での塩分濃度の変化は, 例として 0.4

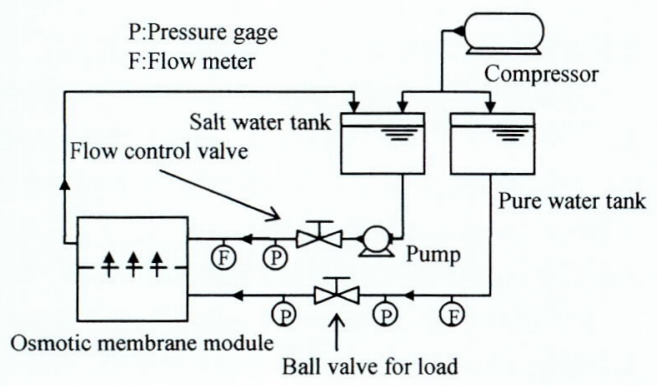

Fig. 1 Outline drawing of experimental equipment wt\%から 0.375 wt\%へと減少する程度である.

\section{4. 実験結果と考察}

$4 \cdot 1$ 予備実験 図 2 に大気圧下で浸透実験を行 った際の真水流路に設けたバルブ後方 (モジュール側) の様子を示す. 図 2 の写真は実験開始から 10 分後の ものである. 実験条件は塩分濃度 $4.0 \mathrm{wt} \%$, 真水およ び塩水水温は $283 \mathrm{~K}$, 塩水流量はモジュール内塩水流 路平均流速が $5 \mathrm{~cm} / \mathrm{s}$ (塩水流路圧力 $0.003 \mathrm{MPa}$ )であ る.また, バルブは全閉状態である.

実験開始前 (ポンプ始動前)には見られなかった気泡 が, 図 2 より, 実験開始から 10 分経過後には, バルブ 下流側に発生していることが認められる.これは浸透 圧によって真水が塩水側に浸透したことにより, 浸透 膜モジュールの真水流路を含むバルブ下流側の圧力が 水の飽和蒸気圧以下となったためであると考えられ る.この大気圧下での予備実験の塩分濃度を 4.0 $\mathrm{wt} \%$ とした理由は, 塩分の濃度を実際の海水として模 擬し, 浸透圧の影響を明確にするためである。この予 備実験以降の実験においては, 塩分濃度 $4.0 \mathrm{wt} \%$ の浸 透圧 $2.8 \mathrm{MPa}$ に抗う圧力を加えることは装置が複雑 になることから, 塩分濃度を $0.6 \mathrm{wt} \%$ 上限として, 大気圧下および加圧下での実験を行なった。

また, 塩分濃度を $0.4 \mathrm{wt} \%$ (浸透圧 $0.32 \mathrm{MPa}$ )とし， 大気圧下および系を $0.5 \mathrm{MPa}$ 加圧した状態で同様の 実験を行ったところ, 大気圧下の実験ではこの気泡の 発生を目視により確認したが, 加圧下の実験では気泡 の発生は確認されなかった.このことは, 系を加圧す ることによりモジュール内および真水流路内が負圧に なることを抑えられたことを示すものである.よっ て, 製作した装置の“負圧による気泡の発生を抑え る”という目的は達成したといえる.

\section{$4 \cdot 2$ 大気圧下および加圧下での浸透流量の測定}

図 3 に, 系の圧力が大気圧および $0.5 \mathrm{MPa}$ におる 浸透流量の時間経過に対する変化を示す. 実験条件と

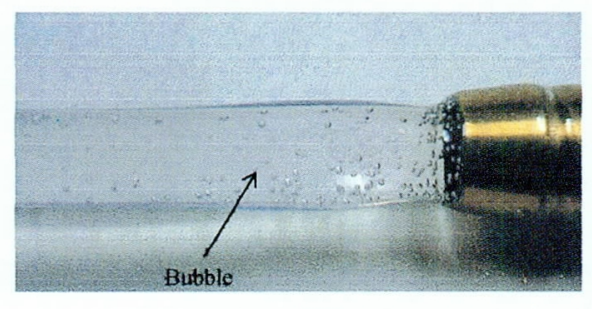

Back of valve. (module side)

Fig. 2 Photo of pure water channel in the neighborhood of ball valve 


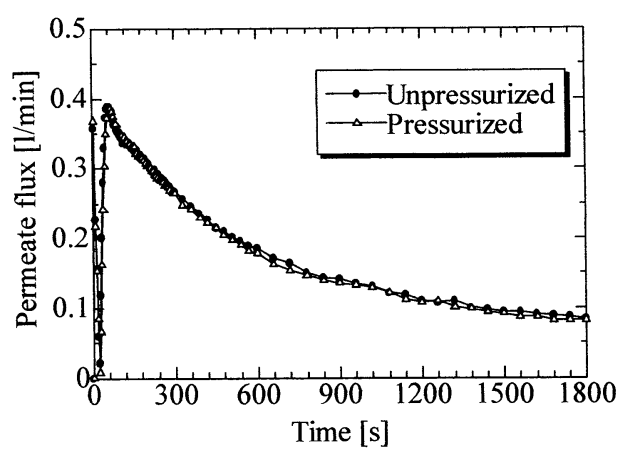

Fig. 3 Permeate flux vs. time at atmospheric pressure and at $0.5 \mathrm{MPa}$ (Salt concentration : $0.4 \mathrm{wt} \%$ )

して, 塩分濃度は $0.4 \mathrm{wt} \%$, 真水および塩水の水温は $288 \mathrm{~K}$, 塩水流量はモジュール内塩水流路平均流速が $5 \mathrm{~cm} / \mathrm{s}$ となるように調節した。真水流路に設けたバ ルブの開度は全開とした。また，ポンプによって塩水 の循環を開始した瞬間を 0 秒としている.

大気圧下および加圧下のいずれにおいても塩水循環 開始直後に浸透流量は極大值に達するが，その後 $0 \mathrm{~L} /$ $\min$ まで減少した後, 急激に増大して極大值に到達 し，その後徐々に減少していく様子を確認した．前者 の極大值は，塩水を循環させるためにポンプを始動さ せたことにより塩水側の圧力が上昇し，浸透膜のわず かな変形などにより生じた真水流路の逆流を微少流量 計が感知したものと考えられる.つまり後者の極大值 以降の流量が, 本研究で目的とする浸透による流量で ある。

また，前述したように大気圧下の実験において，モ ジュール内真水流路に気泡の発生を目視により確認し たが, 図 3 を見る限り, 大気圧下の浸透流量は加圧下 のそれとほとんど同じであり，明確な違いは確認でき ない.さらに, 大気圧下および加圧下での浸透流量を 比較する実験は 0.1，0.2，0.6 wt\%においても同様に 行った.しかしながら， $0.4 \mathrm{wt} \%$ での実験と同様に， 両者の明確な差は見られなかった。つまり, 予想した 気泡の発生による浸透流量の減少は認められなかっ た.したがって, 塩分濃度 $0.6 \mathrm{wt} \%$ 程度までの浸透実 験(水車負荷なし)では, 膜面の気泡の発生による浸透 流量の低下はないと結論付けてよさそうである。

以上より, 後者の極大值を示した後, 時間経過とと もに浸透流量が減少していくのは, 真水の浸透によっ て塩水側膜表面近傍の塩分濃度の低下が生じ, 浸透圧 が減少したことが主な原因であると考えられる。

$4 \cdot 3$ 浸透流量に及ぼす塩分濃度の影響 図 4 に は $0.5 \mathrm{MPa}$ 加圧下における塩水の塩分濃度 $0.1 \mathrm{wt} \%$

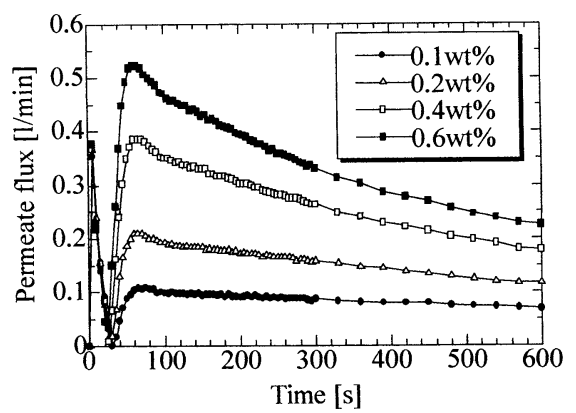

Fig. 4 Effect of salt concentration on permeate flux

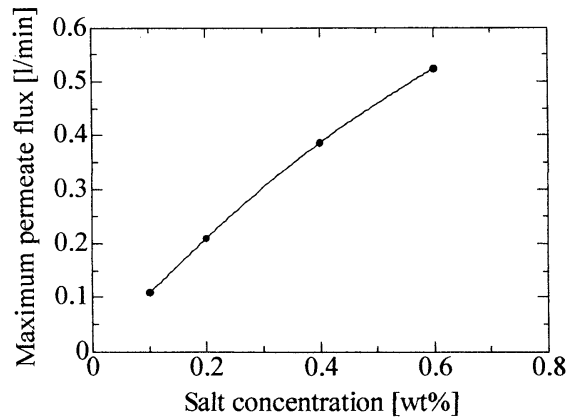

Fig. 5 Relation between maximum permeate flux and salt concentration

から $0.6 \mathrm{wt} \%$ の各濃度における浸透流量の時間経過 に対する変化を示す。ここで, 塩水流量は $5 \mathrm{~L} / \mathrm{min}$ ・(モジュール内塩水流路平均流速抢よそ $5 \mathrm{~cm} / \mathrm{s}$ ) とな るように塩水流量調節バルブによって調節し, バルブ 開度は全開とした. 浸透流量の時間経過に対する変化 は，どの濃度においても図 3 と同様に二度目の極大值 を示した後, 減少していくという傾向を示した。また， 時間経過に対する減少の割合は, 塩分濃度が濃いほど 大きくなっていることがわかる.

また，図 5 には各濃度において得られた最大浸透流 量を示した。図 5 において, 当然のこととはいえ, 塩 分濃度が濃いほど浸透圧が増大するため, 浸透流量は 増大している。 また, 図 5 より, 塩分濃度と最大浸透 流量は完全な比例ではなく, 濃度が濃くなるほど, 最 大浸透流量の増加が鈍くなる傾向にあることがわか る.この傾向は, 濃度が濃い注ど, 前述した真水の浸 透による塩水側膜面近傍の塩分濃度低下の影響が大き く現れるためであると考えられる.

\section{$4 \bullet 4$ バルブ前後差圧に及ぼす塩分濃度の影響}

$4 \cdot 3$ 節と同様に塩分濃度を $0.1 \mathrm{wt} \%$ から $0.6 \mathrm{wt} \%$ の 間で変え, バルブ開度の実験条件のみを全閉と変更し て同様の実験を行った。図 6 に, 各濃度のバルブ前後 


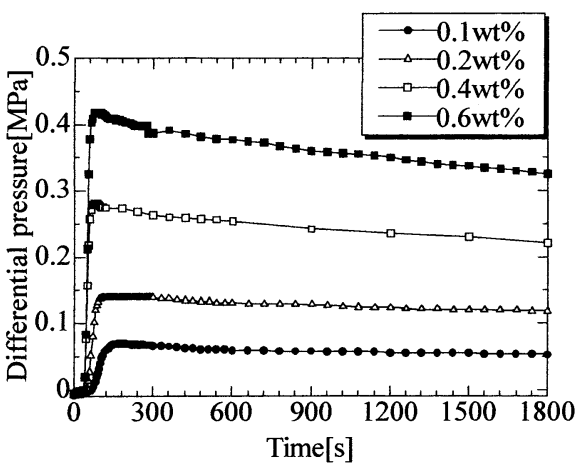

Fig. 6 Effect of salt concentration on differential pressure between valve inlet and outlet

差圧の時間経過に対する変化を示す。ここで興味深い のは，どの塩分濃度においてもバルブ全閉における差 圧が極大値に到達した後, 徐々に減少していることで ある。

本来ならば, 真水の供給が止められているために, モジュール内真水圧力は浸透平衡に到達したときの圧 力を保つはずである．この現象は次のように考えるこ とができる. 実験開始後, 浸透膜を介して真水と塩水 が接した後，まず，浸透により，モジュール内真水流 路中に保持されていた真水が塩水流路へと流出する. すると真水の供給は止められているために, 真水流路 内は塩水流路内の圧力に比べ急激に圧力降下が生じ る。关の圧力差に加え，浸透の場合に扔いても，逆浸 透の場合と同様に浸透膜の塩分阻止率が $100 \%$ ない (ここで, 本研究に用いた逆浸透膜の逆浸透に対する 阻止率は $99.6 \%$ ) と考えると, 浸透膜を介して, 微量 ながら塩分が真水側へと流れ込む。 すると真水側の塩 分濃度が増加し, 膜を介した真水側と塩分濃度差が減 少する。これにより，その分だけ浸透圧が隇少する。 そしてそれと平衡状態を保つために塩水側から真水側 へと真水の逆浸透が生じ，その分，モジュール内真水 流路圧力が増加する。このために, 得られるバルブ前 後差圧は極大值を示した後, 時間とともに減少したも のと考えられる。したがってこの結果から，実験に使 用した逆浸透膜モジュールを浸透に用いた場合にも， 逆浸透と同様に僅かながら真水側への塩分の漏洩があ ると言える.この塩分の漏洩もまた，図 4 に示す時間と ともに浸透流量が減少する原因の 1 つと考えられる.

図 7 には各塩分濃度に扑てて得られた最大バルブ前 後差圧を示した。 また, 図 7 には文献 $(5)$ 加得た各 濃度における浸透圧も示した。 図 7 から, 各塩分濃度 に対応する浸透圧に対して, 得られた最大差圧は小さ

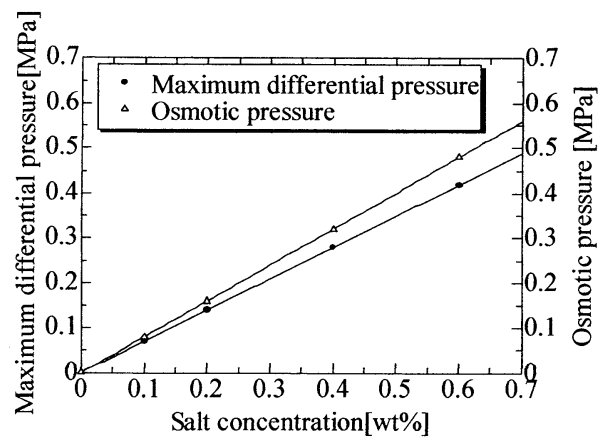

Fig. 7 Relation between maximum differential pressure and salt concentration

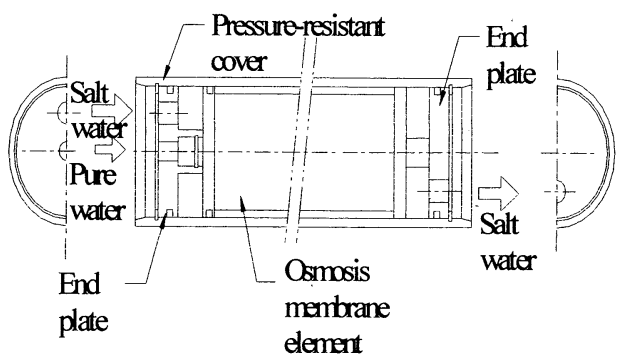

Fig. 8 Diagrammatic illustration of spiral wound module

な值を示していることがわかる，さらに，濃度を高く するほどその差は大きくなっている。しかしながら， 各濃度における最大差圧は，それぞれの浸透圧のおよ そ $87 \%$ と一定の割合で小さいことがわかる。これに ついても前述したように, 漫透した真水によって, 膜 を介した塩分濃度差が低くなったことが影響している ものと考えられる.

$4 \cdot 5$ 浸透膜モジュール形状に関する考察＼cjkstart本節 では，スパイラル型浸透膜モジュールを塩分濃度差発 電に用いることに関する問題点について考察する.

$4 \bullet 4$ 節で述べた真水流路側への塩分の浸透は, 市販 のスパイラル型浸透膜モジュール(図 8) を塩分濃度差 発電に対して使用することの限界を示唆するものであ る.このモジュールは, 真水収集管に封筒型をした浸 透膜を取り付け，真水収集管を中心に巻きつけた構造 をしている。ここで, 真水流路はその封筒型をした膜 の内側であるが，塩水流路からの塩分の浸透がある場 合, 膜の構造上, その浸透してきた塩分を排出するこ とができない.これは時間とともに浸透流量が減少す る一つの要因であると考えられる.このことから，ス パイラル型浸透膜モジュールは, 塩分濃度差発電を持 続的に行うことを考えた場合, 不向きであるといえる.

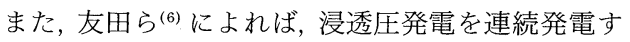




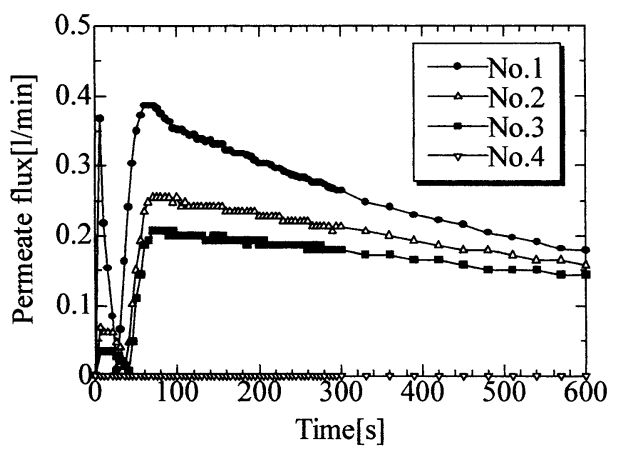

Fig. 9 Effect of valve opening on differential pressure between valve inlet and outlet (Salt concentration : $0.4 \mathrm{wt} \%$ )

るためには, 4 開口(塩水入口・出口, 真水入口・出 口)の浸透膜モジュールが必要であるとしている。こ れは本研究において塩水側膜面に新鮮な塩水を供給す るために流れを与えたのと同様に, 真水側膜面にも新 鮮な真水を供給することを目的として, 真水流路にも 流れを与えるためである。これにより, 前述した真水 流路内への塩分の浸透の影響を抑制できる. 友田らは 中空糸膜を用いて 4 開口耐圧モジュールを試作し, 実 験を行っている.その結果は 50 時間の連続運転にお いても，浸透流量の劣化は見られないというものであ った.

本研究においても友田らが試作した 4 開口耐圧モジ ュールを用いるべきとも思われるが，それに比較して 構造が単純で, 内部流れのモデル化もより容易であり, 性能予測がし易いこと，また，安価であることを考慮 し, 本研究には市販のスパイラル型浸透膜モジュール を採用した、スパイラル型のそれらの性質は，実用化 に際しては，まだ改良の余地があるとはいえ，重要な ことと思われるので基礎データを得ることとした。

$4 \cdot 6$ 浸透流量およびバルブ前後差圧に及ぼすバル ブ負荷の影響 図 9 にバルブの開度を変えて実験を 行った場合の, バルブ前後差圧の時間変化を示す.

実験条件は $4 \cdot 2$ 節の加圧下の場合と同じである. 図 9 中の表示 No. 1 から No. 4 は, バルブの開度を表し ている.No.1がバルブ全開, No. 4 が全閉であり, No. 2, 3 はそれらの途中のものである. また, バルブ 全開においては，その差圧は読み取れないほど小さな

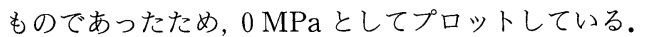
当然のことながら, バルブの開度を小さくするほど差 圧は増加している。 また図 10 には図 9 の差圧に対応 した浸透流量を示す。図 9,10を併せてみると, 各バ ルブ開度における最大差圧と最大浸透流量の得られる

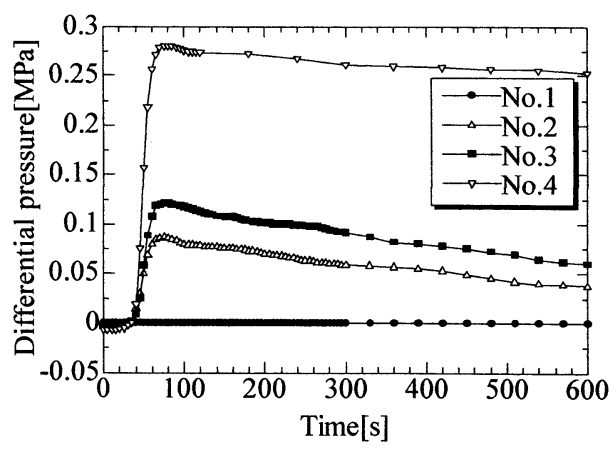

Fig. 10 Effect of valve opening on permeate flux (Salt concentration : $0.4 \mathrm{wt} \%$ )

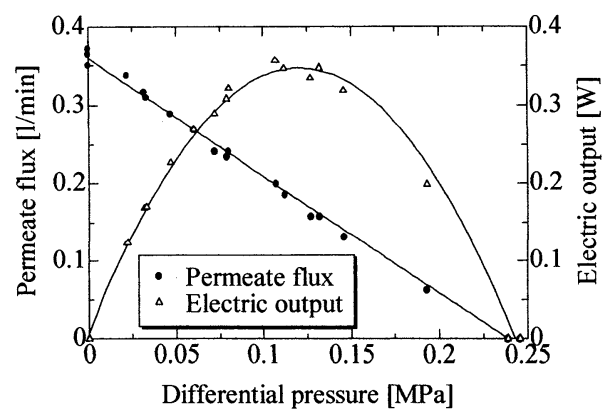

Fig. 11 Output performance curve (Salt concentration : $0.4 \mathrm{wt} \%$ )

時間が一致していることがわかる．また，前述したよ うに, 各最大值を示した後, 時間の経過とともにその 值は減少していく様子がわかる。

$4 \cdot 7$ 発電性能 図 11 に, 本研究で作製した実験 装置を，塩分濃度 $0.4 \mathrm{wt} \%$ の塩分を用いて作動させた ときの性能曲線を示す。横軸には水車負荷を模したバ ルブ前後の差圧をとっている. また, 図 11 にはバル ブ前後差圧に対する浸透流量もあわせてプロットして いる，前述したように，本研究における浸透流量およ び差圧は, 様々な要因により安定した值を示さず, 減 少し続けた。そこで, 各バルブ開度における最大浸透 流量および最大差圧の得られる時間が一致することか ら，発電性能の算出にはそれらの值を用いた。また効 率 $\eta$ は単に $100 \%$ として出力を算出した。

図 11 より, 水車出力の実験点は一本の曲線上に乗 り, バルブ前後差圧が本実験条件で得られた最大差圧 の $0.24 \mathrm{MPa}$ のおよそ半分である $0.12 \mathrm{MPa}$ あたりで 最大出力 $0.35 \mathrm{~W}$ を示している。また, 浸透流量はバ ルブ前後差圧の増大とともに減少して, 一本の直線上 に乗っている. また, 図 12 には塩分濃度 $0.4 \mathrm{wt} \%$ の 性能曲線も含め, 塩分濃度 $0.1,0.2,0.6 \mathrm{wt} \%$ での性 


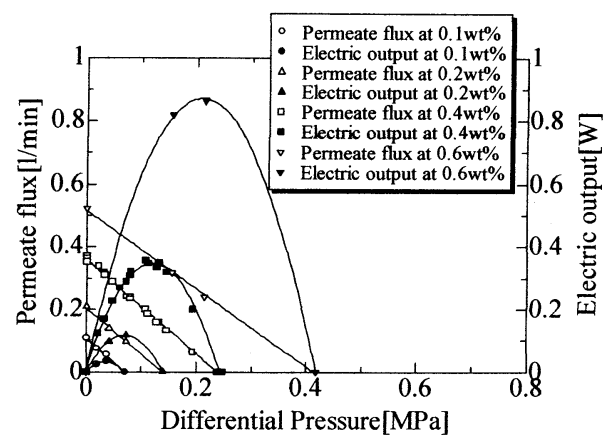

Fig. 12 Comparison of output performance curves

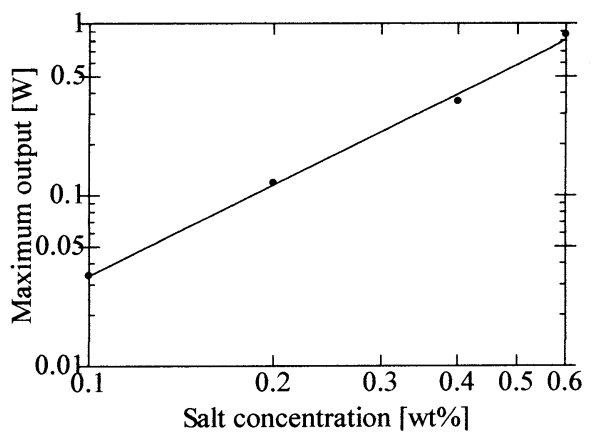

Fig. 13 Relation between maximum output and salt concentration

能曲線を示した. 図 12 から, どの塩分濃度において も, $0.4 \mathrm{wt} \%$ の結果と同様の傾向を示すことがわか る.さらに, 各塩分濃度に打ける最大出力を図 13 に 示す. 図 13 は両対数グラフで示している. 図 13 よ り, 塩分濃度 $0.1 \mathrm{wt} \%$ から $0.6 \mathrm{wt} \%$ 範囲において, 最大出力は塩分濃度の扔よそ 1.77 乗に比例して増大 していくことがわかる。このことは, 式(1)における $Q$ が式(2)中の $\rho_{S}$ (膜近傍の塩分濃度)に, さらに式 （1）における $\Delta p$ が塩分濃度に比例することから，お よそ塩分濃度の 2 乗に比例するという関係を示したも のであるといえる.また，2乗にならない要因として， 図 7 に示したように, バルブ前後差圧が, 浸透圧の 87\%程度になっていることが挙げられる.これは塩分 濃度が濃くなるほど, 真水の浸透の影響により, 膜を 介した塩分濃度差が低くなるためだといえる。

\section{5. 結 論}

本研究では, 実用化を考慮に入れて系全体を加圧出 来るように超小型浸透圧塩分濃度差発電試験システム を構築し, 塩分濃度 $0.1 \mathrm{wt} \%$ から $0.6 \mathrm{wt} \%$ の塩水お
よび真水を用いて, その発電性能を実験的に検証し た. 得られた結果の主なものは以下のとおり.

（1）膜面積 $4.318 \mathrm{~m}^{2}$ の浸透膜を用いて製作した 塩分濃度差発電システムの超小型装置の出力は, 水車 効率 $100 \%$, 塩分濃度 $0.6 \mathrm{wt} \%$ として, 最大でおよそ $0.86 \mathrm{~W}$ であった。

（2）塩分濃度 $0.1 \mathrm{wt} \%$ から $0.6 \mathrm{wt} \%$ にいて, 製作した装置の最大出力は, 塩分濃度のおよそ 1.77 乗に比例した。

（3）濃度差発電システムを加圧下で作動させた場 合, 真水流路が負圧になることを防ぎ, 真水流路にお ける気泡の発生を抑えられた。

（4）浸透流量は, 最大浸透流量が得られた後, 時 間経過とともに減少した。これは主に浸透した真水お よび塩水により, 膜を介した濃度差が小さくなったた めである.

（5）塩分濃度 $0.1 \mathrm{wt} \%$ から $0.6 \mathrm{wt} \%$ までの塩分 濃度の増加に対する最大浸透流量の増加は, 塩分濃度 にほぼ比例した。

（6）塩分濃度差発電システムを大気圧下で作動さ せた場合, 僅かながら真水流路が負圧になるため, 真 水に溶存している気泡の発生を確認したが, 浸透流量 に影響はなかった。

\section{文献}

(1) Ihara, A., Watanabe, H., Hashimoto, H., Kawano, S. and Katagiri, K., Flow Test through Semipermeable Membranes with Salinity Difference between Pure Water and Sea Water for Foundation of Hydraulic Power Plant, Transactions of the Japan Society of Mechanical Engineers, Series B, Vol.62, No. 596 (1996), pp. 1454-1458.

(2) Yasugahira, W., Tsukada, Y. and Ihara, A., Performance Prediction of Hydroelectric Power Station Utilizing Osmotic Pressure as Driving Force, Transactions of the Japan Society of Mechanical Engineers, Series B, Vol. 69, No. 677 (2003), pp. 75-81.

(3) Shiono, A., Yasugahira, W. and Ihara, A., Basic Research of Hydroelectric Power Station Utilizing Osmotic Pressure between Sea Water and River Water, Proceedings of the 20th Annual Meeting of Japan Society of Energy and Resources, No. 28-1 (2004-1), pp. 501-504.

(4) Rautenbach, R. and Albrecht, R., Membrane Processes, (1994), pp. 48-171, John Wiley \& Sons.

(5) Oya, H., Design Method of Processes of Membrane Separation (in Japanese), (1985), pp.61-88, Kitamishobo Ltd.

(6) Tomoda, T., Asami, T., Mano, H. and Matsumoto, T., Experimental Study of Power Generation by "Pressure Retarded Osmosis" under Flow Conditions, Proceed ings of the 20th Annual Meeting of Japan Society of Energy and Resources, No. 28-2 (2004-1), pp. 505-508. 